\title{
BENEATH THE BODY OF THE TEXT: BODY-IMAGES IN THE SONG OF SONGS
}

\author{
Pieter van der Zwan \\ Post-doctoral research fellow, University of Pretoria \\ E-mail: pvdz1961@gmail.com
}

(Received 31/03/2017; accepted 11/04/2017)

DOI: https://doi.org/10.25159/1013-8471/3671

\begin{abstract}
The various explicit references and descriptions of the different bodies in the Song of Songs have, just as characters, an "unconscious" which can be interpreted by psychoanalysis. These body-images are important as they unconsciously influence the recipients of the text and therefore need to be unpacked in a critical way. This will hopefully also show that the literal interpretations are flat reductions and a denial of a hidden depth of meaning.
\end{abstract}

\section{INTRODUCTION}

This study reacts against the "literal" interpretation(s) of the Song of Songs in that it refers to the "unconscious" of the Song, that which is not said. A psychoanalytic perspective is therefore used in the interpretation of the body-images in the Song without limiting it to a particular representative of psychoanalysis. This "unconscious" has many different facets, one of which is the body-images underlying the explicit descriptions of the lovers' bodies. After an initial hermeneutic to explain and justify this research, the bodies of the two lovers as they are mentioned or described, as well as all other bodies which refer to these lovers, will be unpacked. Thereafter, these explicit textual data will be interpreted from a psychoanalytic perspective to show their underlying, unconscious body-images. Translations are from the 1917 Edition of the Jewish Publication Society.

\section{HERMENEUTICS}

A hermeneutics of suspicion, to use Ricœur's (1965:passim) concept, demands that the flat reduction of the literal interpretation, the flatland view, to use Wilber's 
expression (2001:19-21), is regarded only as an outward presentation, behind and below which hides the essence of a text. From a psychoanalytic perspective the text is merely the conscious expression of an author or authors.

One can say that the text also has a kind of an "unconscious": even if the text expresses the conscious intentions of the author, recipients usually find additional meanings not consciously intended by the author. This unconscious interacts with the unconscious of the recipient and can therefore, through a Horizontverschmelzung (merging or fusion of horizons), to use Gadamer's (1960:394) phrase, without limiting it to the unconscious meaning, influence the unconscious of the recipient. That is why it is important to trace the contours of this textual unconscious. One part of that textual unconscious concerns body-images which are, of course, always relative to a context. Presentations of body-images sculpt that of the recipient, not only through the media but also through reading scripture.

Body-image is culturally and, ultimately, psychologically determined, and a reflection of the social body which it in turn also influences (Murphy 1992:162-165). Because the original or developmental context of the Song is unknown, one has to stay with relatively universal findings of psychoanalysis about body-images.

On the surface, the Song is about bodies, which, of course, imply body-images. Below the conscious description there are unconscious images and phantasies about the body which one can analyse psychoanalytically. Although the term "body-image" is technically used for conscious views of the body and "body-scheme" for the unconscious perception of the body, this study will use "body-image" for both conscious and unconscious images of the body.

These are clearly different from the body-images in, say, Leviticus 21-22, even if both biblical texts portray an idealised body (van der Zwan 2017, forthcoming,). ${ }^{1}$ Although only certain body-parts are mentioned, these are like dots which form an outline, inviting the reader to participate in it with his or her own fantasies: there are no clear faces (which is ironic: vide infra) or forms (fat or lean), only their effects: the male lover swoons in 4:9 due to one of her eyes and a bead of her necklace, and again

1 Both exclude any (imperfection) from the body. 
in 6:5 due to her eyes; as she is love-sick through her desire for beauty and pleasure in 2:5 and 5:4; and 8, where she is paralysed by his wonderful presence. In 3:11, 4:9 (twice), 5:2, and 8:6 the heart functions as psychosomatic centre of emotions. In four of these five occasions that the heart is mentioned, it refers to the male lover. These ten verses above are the only references to what each body is experiencing internally; otherwise they are portrayed only from the outside.

Despite the general view of commentators that the two lovers mirror and balance each other, this is not the case when it concerns their bodies which are rather complimentary to each other: what has been left out for the one, is mentioned for the other.

\section{SURFACE DESCRIPTIONS OF THE BODIES IN THE SONG}

One reads about the body in every chapter of the Song and, indeed, almost in every verse, and in total 24 body-parts are explicitly mentioned, and once the "palms" of the door handle which could in this context suggest the female's genitals. Only two of these body-parts are mentioned more than five times: her breasts (eight times or 47 times if the stem, 7 , which occurs 39 times, is regarded as a double entendre to mean both love and breasts or at least to suggest the latter [cf. Brown, Driver \& Briggs 1907:186]) and the eyes (seven times).

Direct, clustered descriptions are found in the four auṣâf (descriptions) in 4:1-7, 6:4-7, and 7:2-8 (although the exact ending verse of each can be disputed) about the female lover, and 5:10-16 about the male lover. Of course, these descriptions are in the mind of the partner, although beyond the aușâf (descriptions) the female lover also describes her own body, but the male never mentions anything about his own body. This could mean that the male gaze is outward towards the appearing body of the other, whereas the female looks outward too, but also "inward", to herself. Incidentally, this is the biblical book with the most references to the first person, coming by far mostly from the female lover. 
Each body can therefore be described by the person who "is" that body and by others. Although there are various characters in this drama, there are only two human bodies: those of the two protagonists. The others are rather either bodiless voices, such as the daughters of Jerusalem, or actors, such as the guards who nevertheless remain invisible. The three exceptions are the mothers of the lovers, in 8:1 and 8:5 respectively, mentioning only the suckling breasts of her mother and the labour pangs of his mother. The reference to the thighs or hips of the bodyguards in 3:8 possibly has an erotic connotation as it is linked to a "sword", perhaps a phallic symbol of potency (amongst a mere handful in the Song), apart from the fact that the thigh was archaically sometimes an euphemism for the penis, as in Genesis 46:26 and Exodus 1:5 (Keel 1986:214), and the most holy body part by which an oath was sworn. The focus in all three instances therefore seems to be on essential sexual features of these bodies.

The human bodies in the Song could at times be naked, especially that of the male lover, because clothing is mentioned only a few times and then always in connection with the female lover: a veil in $1: 7$, a veil in $4: 3$, her garments in $4: 11$, a coat in $5: 3$, a veil or mantle in 5:7, a veil in 6:7, and sandals in 7:2. Added to that, is her decorative jewellery in 1:10-11 and 4:9.

Clothing and all kinds of beautification extend the body to material objects, such as clothing, as often happens elsewhere. Yet her jewellery in 1:10-11 fulfils that role in the beginning. Other body-parts, such as the ears, get no explicit attention, although hearing is repeatedly referred to.

\section{The female body}

The first reference the female lover makes to her body is in 1:5-6 when she seems to be uncomfortable with her dark skin, although her neck is as if it is of (ivory) in $7: 5$. She is also the one who makes her first praise-remark concerning her lover in the wasf $^{2}$ (description) in 5:10-16 about his skin, again, as in the first chapter, without

2 This is an Arabic term referring to the praise of human, but mostly feminine, pulchritude on love poetry and has survived to the present day in various countries in the Middle East 
mentioning it explicitly. Again it concerns its colour but his is the opposite of hers. In 5:10 he is said to be צִ וָדָדוֹם (white and ruddy), and in 5:14 his abdomen, loins or torso עִשֶׁת (as polished ivory). Viviers (1998:5) regards a light skin as a male-valued and male-conditioned body ideal, according to Lamentations $4: 7$, which the city girls had internalised and therefore made the beloved self-conscious when they stared at her. There might be an issue with her body-boundaries here, a fundamental aspect of body-image (Fisher 1989:54). This could be related to the numerous virtual, or at least imaginative, identifications with the animals in their natural environment, but that applies to the male lover then as well (vide infra).

When the body is unconsciously projected outward, as Mary Douglas (1970:165) claims, then her body-boundaries can be related to the social body-boundaries. These one can recognise in both the law, which is completely absent in the Song except when it is suggested by the city-guards and the city-walls, or more concretely in architectural structures such as walls, a symbol which is, in fact, taken up in 8:9-10 where it probably refers to her hymen (cf. Pope 1977:683). This is followed in the next verse by the metaphor of a door, which implies access to her body (vide infra).

Apart from referring to her skin in 1:5, she is also the one who refers - and this time explicitly - in 1:13 to her breasts with which she identifies with tenderness. References to her breasts frame the Song as they are again mentioned by her at the end, in 8:10, where she claims that they are like towers (vide infra), priding herself in what her brothers have doubts about.

It would seem that the male lover clearly notices her breasts above all else. Pope (1977:636) has even translated then his argument about the sequential description can no longer be sustained.

Compared to her other facial parts such as her lips (4:3; 4:11; 7:10), mouth (4:3), teeth (4:2 and 6:6), tongue (4:11), palate or gums (2:3), cheeks (1:10), nose (7:5), and temples (4:3 and 6:7) her eyes seem to be the essence of her face, although the word,

(Pope 1977:67). They were originally perhaps descriptions of statuaries in the hymns to the gods (Munro 1995:60). 
פִפְנִים (face), or its derivatives, never occurs in the Song (Baumann 2003:224). The word, (your face), ${ }^{3}$ in 7:9 does, however, occur (vide supra).

It is perhaps significant in a subtle way that the first proper name for a place, עִין (ֶֶ? (Engedi, Kid's Spring), in 1:14 could be recognised in the unconscious for its homophonic alternative meaning of the "eye" precisely because in the very next verse her eyes are the first of her body-parts that the male lover singles out without connecting it to any jewellery, as he has done earlier in 1:10.

Her eyes are also the first mentioned in the first wașf (description) about her in 4:1-7 which, significantly, closes off with a reference to her breasts in $4: 5$ as the last of her body-parts mentioned in this literary unit. Later, in 4:9, the male lover is particularly struck by her one eye, and her eyes are again singled out as overwhelming in 6:5.

The second wasf (description) about her in 6:4-7 follows the same sequence. and sometimes even the same wording, as that of the first (6:5b repeats 4:1b, 6:6 only

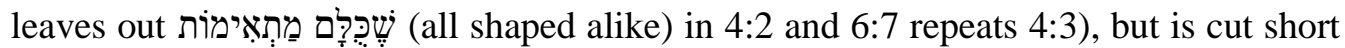
after mentioning her temples and leaves out her lips and mouth. Both aușâf (descriptions) start with a general statement about her beauty in 4:1 and 6:4 respectively.

The third wașf (description) about her in 7:2-8 is different from the previous two in that it starts from her feet and curvy thighs in 7:2 and moves upwards, describing her pelvis area in 7:3, towards her head in 7:5-6 where her neck, eyes, and nose are קָרוֹעִים

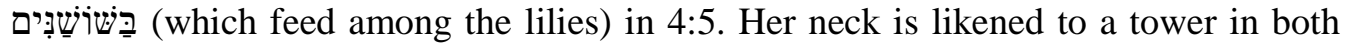
auṣaff (descriptions), in 4:4 and 7:5 (vide infra), but in the first it is connected to David and military images. Her hair, which is likened to sheep in 4:1 and 6:5, probably due

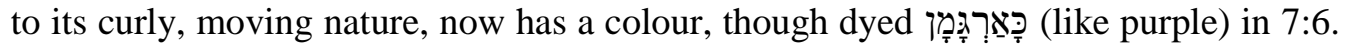
The wasf (description) opens with a general statement (probably not only limited to

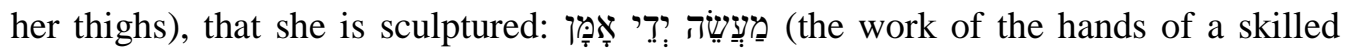

3 The noun, §ֵ, can have various meanings, the most common one being "nose" (cf. Pope 1977:636-637), but it can also mean "face" or "anger" (Brown, Driver and Briggs 1907:60). 
workman), where the recipient can virtually feel the creative touch which shapes her into a dancing artist herself. This parallels the statue of the male body as a sculpture in 5:14-15 (vide infra), but it also extends and "interiorises" the jewellery in 1:10-11 and 4:9 as works of art then attached to her body but now, so to speak, becoming her body as a work of art. If this wașf (description) ends with 7:7, the same general statement about her beauty is made as in 4:7 which closes and frames the first wasff (description) opening with a similar inclusive view in 4:1 (vide supra).

Her total body seems to have a rather phallic image as a palm in 7:8-9, reinforcing the same symbolism used for her neck in 4:4 and 7:5 (vide supra), her nose in 7:5, and even her breasts in 8:10 which are all likened to towers (vide supra). This phallic pride and aggression of her body may be reinforced by the different military associations which accompany it, such as her being like a war-horse in 1:9, her neck being

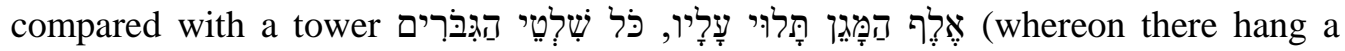
thousand shields, all the armour of the mighty men) in 4:4, and her connection with

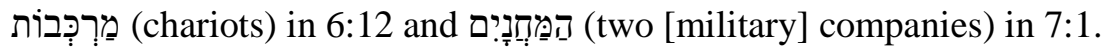

The only two body-parts which occur in all three aușaff (descriptions) are her eyes $(4: 1 ; 6: 5 ; 7: 5)$ and hair $(4: 1 ; 6: 5 ; 7: 6)$, always in close proximity to each other in each wașf (description). Although mention is made of the female body's skin, face, breasts, "belly", thighs, and feet, the focus in general in the Song, however, is clearly on her face and breasts.

In general there is a lack of expression, and therefore most probably, of bodily sensations and experiences, something which one would have expected to be in abundance in an erotic text. In the few instances where this happens, in 2:5, 4:9, 5:4, and 5:8, they are all about how "disturbed" their bodies are emotionally because of love, and therefore rather negative.

\section{The male body}

The male lover never refers to his own body except to his internal experiences in his heart in 4:9. Even when the speech of the female lover dominates the Song, his body is described far less than hers. She rather mentions what his body can do to hers. 
She starts with his mouth in the first verse after the title, but refers to its tactile and gustatory pleasure, not its visual appearance. In the last chapter, in 8:1, she reverts to his mouth when she wants to kiss him in public. His smells follow after his mouth in $1: 3$ and 1:13, following perhaps into the next verse as well, and mentioned again in 3:6. Yet his body remains invisible until the wașf (description) in 5:10-16, where four of the seven verses focus on his face, closing this section off once again with emphasis on his mouth in 5:16, and that even after his general appearance has been summarised in the verse before it.

This wașf (description) is quite different from the three which describe the female lover in that his body-parts are not only compared to animals and plants, but also portrayed as shining, yet dead, solid material, suggesting the monumental statues (Gerleman 1965:69) of deities which were, like figurines, probably regarded as the deity's body. It is as if the majestic and detailed litter of Solomon in 3:6-10, described as containing his body, has now been complemented. One is also reminded of the vision in Daniel 2:31-33 of a statue made up of various metals as well.

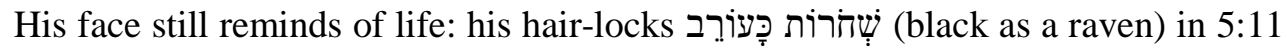

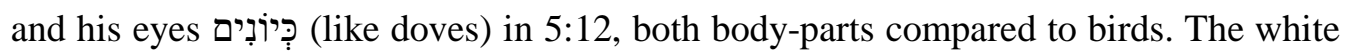
of his eyes, skin, abdomen, loins or torso, and legs is contrasted to the black of his

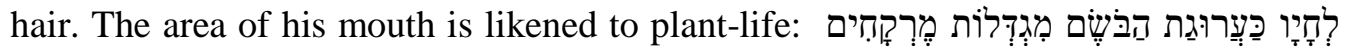

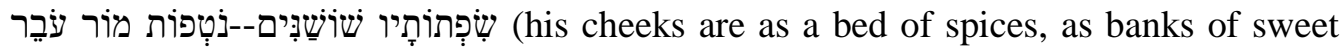
herbs; his lips are as lilies, dropping with flowing myrrh). This is how the female lover experiences his mouth area: how it smells and tastes when she kisses him, not what they are like visually.

It is as if the female lover faces a taboo when she describes the part of his body below his face with dead matter. One senses that something is censored here (and his "feet" never mentioned) and perhaps, therefore, idealised. It is precisely here that his body becomes like a static statue, even when his head was already of gold. Where the female lover wears precious metals in her jewellery, the male lover's body itself is like a jewel. The extremities of his body are all of gold and could serve as some kind of merism suggesting that his whole body is actually gold covered with inlaid gems. 
Three words are used for gold: כֶֶֶּ (poetic and late [Brown, Driver and Briggs 1907:508]) in 5:11 refers to the lover’s head, זָ for his hands in 5:14, and (pure, refined gold) in 5:15 to the pedestals on which the pillars of his legs are set. Despite the similes in many translations there are no explicit comparisons here: his body below his face is simply described as being these materials.

His arms are not mentioned in this wașf (description), and his hands and legs get scant attention in one verse each, in 5:14 and 5:15 respectively, and then so disguised behind precious metal, gems, and stone that they remain as good as invisible: his

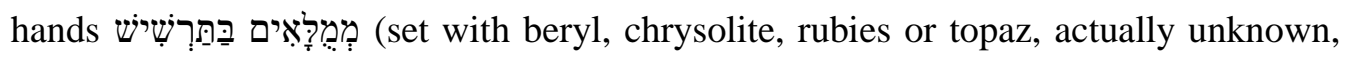
but used in the priest's breast-plate in Exodus 39:13), perhaps referring to his rings,

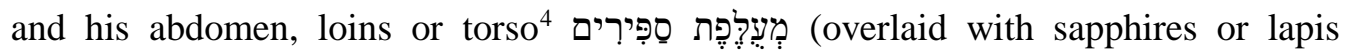
lazuli), both gemstones probably bluish in colour (Pope 1977:543-544). His hands actually involve his fingers as they are rods. According to Munro (1995:63), the

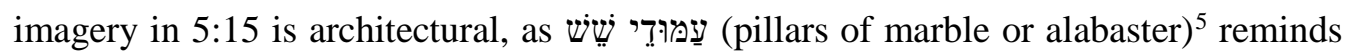
one of the columns of the tabernacle (Exodus 27:10, 11, 17; 36:38; Numbers 3:37), of Solomon's palace (1 Kings 7:2, 3, 6) or of those before the temple (1 Kings 7:15; Jeremiah 52:20, 21; 1 Chronicles 18:8; 2 Chronicles 3:15, 17; Ezekiel 40:49). Likewise does (sockets) recall the base of the tabernacle (Exodus 26:19), of pillars (Exodus 27:11; Numbers 3:36), and of the earth (Job 38:6). In Sirach 26:18 the woman is also likened to the golden columns of the tabernacle (Exodus 25:31-40; 26:32). In 1 Kings 6-7 there is also reference to ששׁ (marble or alabaster) when the pillars of the temple are described.

Thereafter only his heart and his arm are mentioned as carriers of the seal of their love in 8:6. Like his two hands or arms holding her, close to the beginning of the Song in 2:6, and again, close to the end in 8:3, they hold her in the Song in totality as well.

4 Hanks (2014:65) suggests "his penis" as a possible translation for מָעָיו, perhaps because the word can refer to the source of procreation, including the womb (Brown, Driver and Briggs 1907:589) but the reservation with which the female lover describes the lower part of the male's body makes this unlikely (vide infra).

5 Pope (1977:546) refers to Harper to justify the choice of alabaster over marble: as the lover is an Oriental, a brownish colour would be more suitable. This is also the only meaning of the word given in Brown, Driver and Briggs (1907:1010). 
Yet they remain invisible, their value is what they do to the female beloved. His general appearance is like the Lebanon-mountain and, more specifically, its cedars in $5: 15$, just as she is like a palm in 7:8.

At the same time, his body is constantly described as moving, as in 2:8, 6:1 and 8:14, hers mostly not, except in 7:1-2 where she is dancing, perhaps even with her

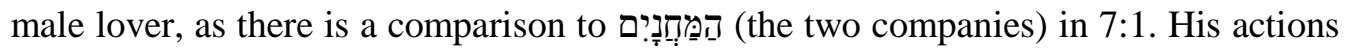
are therefore more important than his looks.

\section{Other bodies}

The female lover is the first to be compared to an animal body, but curiously enough to a male animal, unless an emendation is made in 1:9 (Pope 1977:337). In 5:2 and 6:9 she is called a dove by her lover.

In 2:9 (repeated in 2:17 and 8:14) the male lover is then depicted as הדאָיָלים (like a gazelle or a young hart), the same two animals which she invokes in her adjurations in 2:7 and 3:5. This is most probably due to his vitality and virility but more so because these two animals have a divine connotation. While she was likened to a farm or military animal in chapter one, he is now like game. In this sense she is actually made into a domesticated and disciplined love-object by the male in the same way that her likeness to a garden has the same subtext (Viviers forthcoming).

At the beginning of the second chapter, in 2:1, the female lover refers to herself as flowers: a rose of Sharon and a lily of the valley, probably for visual but also olfactory reasons. The second image is taken by her male lover as a simile in the next verse where he regards other women as thorns compared to her, and again used by her in 6:2 and 3. Then her visual beauty shifts to other sensual delights and pleasures: in 4:12-16 she is likened to a private spice garden of henna, spikenard, saffron, calamus, cinnamon, frankincense, myrrh, and aloes, and mandrakes in 7:14, all with amazing fragrances and delicious and beautiful fruits, such as pomegranates, also mentioned in 6:7 and 11, and 7:13. In 5:1 she is again a garden, now with other foods apart from fruit: honey, milk, and wine. One can almost speak of a kind of synaesthesia where her visual beauty and soft touch become like smells and tastes. A third time this image of 
her as a garden is used, when it is suggested in 6:2, and in 6:11 it is taken up again, now including nuts and green plants as well. In 7:12 she could be the field and in 7:13 she is almost certainly the vineyard, which the reader now realises was actually her already in 1:6 and 2:15, and therefore will be in 8:12 as well. A final time she is suggested to be the lover's garden in 8:13, where he now dwells.

Five times the female beloved is compared to water: in 4:12 a sealed spring and a fountain, in 4:15 again to a fountain, but also to a well and streams of water from the Lebanon-mountain.

In 4:6 she seemingly even becomes a mountain herself, if the male lover does not more specifically refer to her mons Veneris.

In 2:3 the male lover is said to be like an apple or apricot tree, depending on the translation of

Their bodies are therefore identified with the rural environment which is also their love-nest. The extension of the female body goes even further to be likened even to the beauty of the social body as expressed by the two main (competing) ${ }^{6}$ cities, Tirzah and Jerusalem, in 6:4, just as certain of her body-parts are associated with Heshbon, Bath-rabbim, and Damascus in 7:5. As if this is not enough, it gains even cosmic dimensions when it is compared in 6:10 to celestial bodies: Venus presented as dawn (cf. Isaiah 14:12), the moon and the sun, all of which have connotations of divinity in the then culture (Pope 1977:572).

\section{UNCONSCIOUS BODY-IMAGES}

Consciously no whole body can be imagined by a subject or even as an object by others. Therefore the body will always be described partially. The question can be asked why certain, for us obvious, body parts, such as her hands or legs, are not explicitly mentioned. What is not mentioned must have good reasons in the unconscious where it would clearly have been noticed. Two reasons are possible: a

6 One tends to think of the competition for Judaic centrehood between Jerusalem and Samaria, represented by Tirzah, after the exile. Cf. also Pope (1977:558-560). 
certain body-part does not have much meaning, or that it has so much meaning that it should rather be repressed.

It is important to remember that the body-image which a character has of another character might reflect more about the body-image of the former. This applies to the emphasis on the breasts and the eyes of the female lover and that on the mouth of the male lover (vide infra).

From the following it will become clear that the lovers' bodies range between divine and animal images, a phenomenon that Williams (1989:137; cf. also Feher 1989:13) also found to be the continuum along which body-images range in all cultures. Integration of these two opposites is what amounts, in transpersonal psychology, to a higher level of existence, as was already sensed by Otto (2014:6162), when he saw the interpenetration of the lower, animalistic instincts into the next higher level of human feelings and the interpenetration of the higher numinous into the ordinary feelings as an improvement of humanity. This expresses the ambiguity about the body in terms of idealism and realism. The animals with which their bodies are associated, are, however, also carriers of divinity in the mythology to which is constantly hinted. In the animals, the said poles therefore coincide, and in this way they undermine the dualism of modern interpretations: nature is supernatural.

The divine is also suggested in the repeated exclamation about perfection of the bodies of both lovers. The exceptional quality and beauty of the female lover is

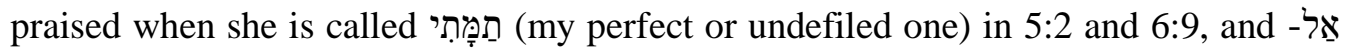

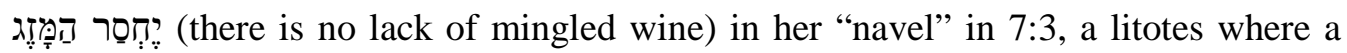
negative is used to emphasise a positive. The same stylistic feature occurs when her teeth are compared to the symmetrical perfection of the descending ewes expressed by

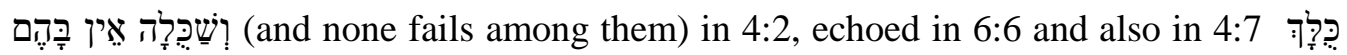

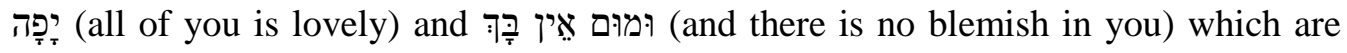
reminiscent of how perfection is regarded mostly in cultic contexts (cf. Leviticus 21:17ff. and 22:20, referring to priests and sacrifices otherwise not being acceptable to

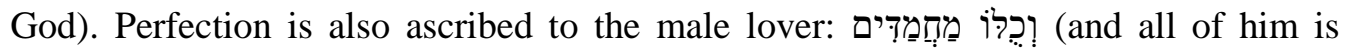
lovely) in 5:16. Asher-Greve (1998:10) claims that perfection was something 
guaranteed by the mother and birth goddesses in the ancient Near East. This would imply that the modern interpretation of it being an exaggeration for stylistic purposes is culture-relative and not loyal to its original sense in the Song.

\section{The female body}

Even when her body is described from foot to head, her body remains fragmented, just as the textual body itself as well. There is a clear focus on her breasts and on her face.

Even if six (1:2, four times in 5:9 and 5:10) of the total of nine mentions of the stem, זר refer to her male lover, his association with her breasts, if this word functions as a double entendre, is so close that the unconscious would probably regard him as an extension of the female's body, just as the infant regards the mother and particularly her breasts during the earliest period as an extension of its own body, rendering any sexual oral pleasure as virtually autoerotic. This is what Winnicott calls primary identification and which Fairbairn (2006:341) describes as, "the cathexis of an object which has not yet been differentiated from the cathecting subject".

The breasts have multiple meanings which are clear from the different things to which they are compared or associated: animals, fruit, money in the eyes of her brother in 8:8, and finally, in the mind of the female lover herself, towers in 8:10 (vide infra).

In the first place, they image the body of the female lover, however, as that of a mother. This is clear from the animal and plant off-spring to which they are compared: in $4: 5$ and 7:4, using almost identical phrases, they are like two gazelle lambs, and in 7:8 and 7:9 to clusters of grapes or of the vine respectively (vide supra). In 8:1 this unconscious connection becomes conscious and explicit when the female lover fantasises that her male lover would suck the breasts of her mother, with whom she clearly identifies, and so uses her just as a cover-up to refer to her own wish to do just that. This fantasy she probably unconsciously cherished in 1:13 already. In 8:8 her brothers' concern is her breasts, and therefore, whether she would have the capacity to serve as a mother, her economic value to her future husband. Freud (1974:107) regards the breast as source of, and therefore later, as paradigm for love for the infant and the 
mature person respectively. With Melanie Klein (e.g., 1975:5), a pioneer in object relations theory, the breast becomes even more important, as if it were competing with the potency of the phallus in Freud's psychology.

All this emphasis on the breasts reminds one of the holy name אל שָשָּי (El Shaddai). El(ohim) introduced himself to Abram in Genesis 17:1 as (El Shaddai). This is usually translated as the Almighty, according to Leeming (2004:92), as El of the mountain, but probably associated with (my breasts, as in 8:10), ${ }^{7}$ as he then also changed Abram's name as a sign of his future fertility. As the first love object in life, breasts clearly relate to the earliest pre-egoic stage relived in nostalgia through the rest of later life.

Although the Song lacks a clear historical context, the emphasis on the breasts as reminder of the lost suckling mother fits in well with the religio-artistic relics from the Ancient Near East, where the earliest Paleolithic representations of the Great Mother Goddess have a relatively small head compared to her accentuated breasts and abdomen (Amansi 1960:61). The jaws, tusks, or beaks of carnivores or dangerous animals are disguised inside female breasts in wall reliefs, symbolising the combination of the nutritious and lethal Mother-Goddess (Cauvin 2000:29). In the southern Levant the female figurines also tend to conform to stereotypes of their symbolic function, for instance, exaggerated breasts and hips. With this emphasis on procreation the Song is therefore closer to the Mesopotamian sacred fertility songs than to the Egyptian erotic poems where procreation is underemphasised, and weaves a fabric of associations with references to breasts and milk.

Yet it was the vulva and the womb, rather than the breasts, which defined women (Asher-Greve 1998:14). Feminine beauty was therefore expressed by metaphors derived from agriculture, whereas erotic pleasure was one of the divine powers (Asher-Greve 1998:23). In the Song the female body is celebrated in her totality, however, because the focus is not on her fertility but on her enchanting beauty. This is already apparent from her male lover when he compares her to a steed in 1:19 without singling out any specific body part, perhaps referring more to her erotic effect. He

7 Cf. Brown, Driver and Briggs (1907:994). 
continues this general view of her body in the first chapter by describing it as beautiful in 1:15-16, mentioning it three times. Her jewellery in 1:10-11 may be an initial screen behind which he slowly starts to describe her body.

That multiple horticultural metaphors are used for her body, does not detract from this, as fruits and flowers are likewise celebrated for much more than as symbols of birth.

There are numerous possibilities to interpret certain of the female's body-parts as euphemisms for her genitals. Her mouth as a female container in 4:3 could have a disguised reference to her vagina (Krinetzki 1981:136). Her navel (שָׁרְרך) in 7:3 could mean her vulva (Loader 1998-2001:105), as it fits the sequential description from below between her thighs in 7:2 and her belly or womb in 7:3b, the latter emphasising it through the only synonymous parallelism in the relevant description (Brown, Driver and Briggs 1907:1057 and Pope 1977:617-618). Her washed "feet" (רגְלִיר) in 5:3 are “a standard biblical euphemism for genitalia” (Pope 1977:381, 517-518). According to Freud (1974:32), body parts such as the feet (or shoes) and the hair, which function as fetishes, do so due to the smell attached to these parts. In addition, especially the feet of women can compensate for the missing penis. In this way fetishes are a

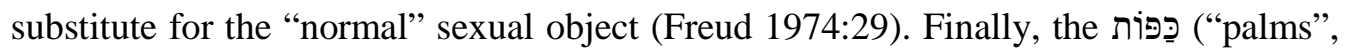
or handle) of the door is perhaps a suggestion which is strengthened by her "hands"

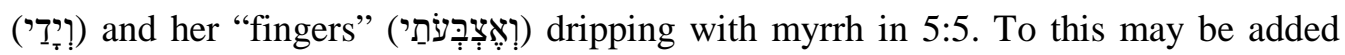
that the beloved's female sexuality is also repeatedly, from 1:6 until 8:12, alluded to in an encoded way as her כֶּר (vineyard). These possibilities, however, cannot be proven as definite suggestions of genital sexuality. Even if they are real, they remain in the background or at least repressed. Their secondary position, or third place if the eyes are taken into consideration, can also be explained by the fact that the female genitals and womb are relatively invisible compared to her breasts, which therefore attract more attention on the exterior.

That her eyes are, together with her breasts, the dominant features in her bodily portrayal is not coincidental. More than half a century ago psychoanalysis discovered the close unconscious link between these two body-parts in the mind of the infant. 
Almansi (1960), building on research done during the fifties, shows that the two percepts fuse but that the mother's breast screens the face which is the first to be noticed. This finding stems from clinical case studies (Almansi 1960:44-58), art (Almansi 1960:58-60), linguistic curiosities (Almansi 1960:60-61), and archaeological discoveries (Almansi 1960:61-65). A Sumerian temple of an "Eye God(dess)" in Brak from the third millennium B.C.E. shows thousands of figures with exaggerated heads with often greater width than heights to accommodate their huge eyes, sometimes four to incorporate those of an infant which implies motherhood, but no other facial features or breasts. It would therefore seem that there is an alternation between showing only either breasts or eyes, and that they are thus exchangeable.

Apart from the eyes, which correlate with the nipples and dominate the Gestalt of the face, the other facial details remain relatively irrelevant. The juxtaposition of her breasts and her face (쪼ำ "your face") in 7:9 provides further support for the close unconscious connection of the breasts and the face for the onlooker. The mutual identification and ultimate equation of the eyes and the breasts boil down to psychological condensation (Almansi 1960:65, 66), so that the one can function as a metaphor for the other: the one reminds one of the other.

Five references to the eyes concern those of the female lover (1:15 and 4:1 [both compared to doves]; 4:9 [struck by her eye]; 6:5 [overwhelming]; 7:5 [like pools]) of the seven (in addition to his 5:12 [like doves and linked to water and milk] and 8:10 [figurative as estimation]). This means that, even though the eyes are mentioned less frequently in the Song, they are actually partially repressed and more strongly cathected than the breasts. The overwhelming nature of the eyes, such as the one in 6:5, probably derives from the infant's experience of the maternal eyes as omnipresent. They could function as mirrors to the observer and serve as selfconfirmation as well, perhaps so in 7:5 where they are reflective like water. It is originally during the oral phase when the maternal eyes are, in fact, more than mirrors: when looking coincides with being looked at and so "embodies both an identification and a projection" (Almansi 1960:68), a kind of imitative magic. The eyes and the 
mouth are then also unconsciously linked so that the eyes incorporate and "devour" the beloved (Almansi 1960:69).

\section{The male body}

Just as the female sexuality is diffuse and tends towards sexualising the whole body, so she describes the male body more holistically than her own is being portrayed. This can be explained from a psychoanalytic perspective according to which the female spreads her sexuality because she lacks a penis, which would have been a limiting focus, as it is for the male.

The female lover's focus on the male lover's mouth, however, might be due to the possibility that their love-play is limited to kissing and embracing. Fisher refers to Fisher and Greenberg (1979) who have proven that people who have emotional conflicts about proximity and distance "have an increased likelihood of experiencing heightened somatic tensions in their major body openings" (Fisher 1989:91). That the female lover might have such issues can be inferred from her desperate search for her absent beloved-lover in 3:1-4, 5:6-7, and 6:1, and her confessions of being love-sick in 2:5 and 5:8.

\section{Other bodies}

The selection of animals, buildings, and celestial bodies are not coincidental. They are associated with the lovers' bodies and mirror them, even if they are mentioned without explicitly relating them to their bodies, such as the leopard and the lion in $4: 8{ }^{8}$

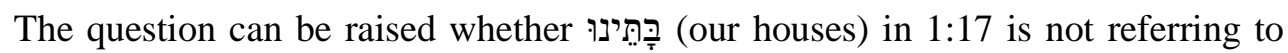
their bodies. As so many features in the first chapter are echoed in the last in order to frame the whole Song, the image of a house recurs again in the last chapter, in 8:8-9

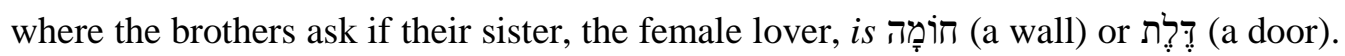

8 All the other animals mentioned are compared to the lovers, except for the foxes in 2:15 which represent the competing "bodies". Therefore these two predators could easily be associated with the lovers as well, as they have energetic and agile bodies. They are also incarnations of the goddess of love in the mythology of the surrounding cultures (Pope 1977:475-477). 
The female lover confirms that she is a "wall”, even when she speaks of החר (the hole, that is, of a "door") in 5:4 and teases her lover in 7:14 with the many "delicacies" waiting at פחתחהינוּ (our doors), perhaps their eroticised orifices. Just as the beams of

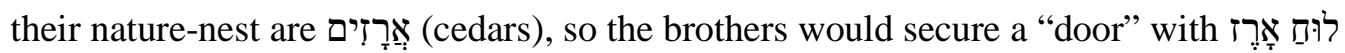
(a board of cedar), and just as רחיטנו (רהּיטֵנוּ) (our panels) in 1:17 shut out the world from the intimacy of the lovers, so the brothers are insisting that the world be excluded from their family property, her sister's body. This shows that both their bodies have been cast into architectural images as the male body has similar features in 5:15 (vide supra).

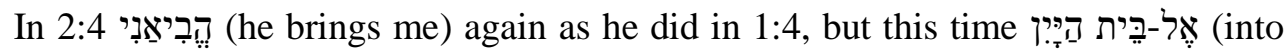
the wine house), a public pub. According to Keel (1986:85), this could also have been a palace room, a summer house, a temporary private house during the harvest which the old Arab poets portrayed as having a notice board, or, as in Egypt and Palestine, a public house for wine and prostitutes.

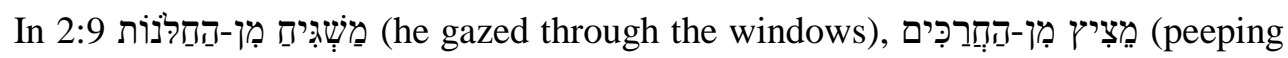
through the lattice, both the verb and the noun are hapax legomena) implies in the

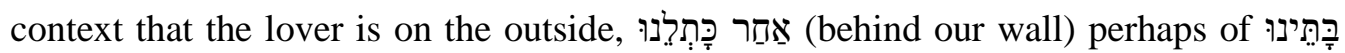
(our houses) in 1:17. Is the house of her mother in 3:4 and 8:2 not her mother's

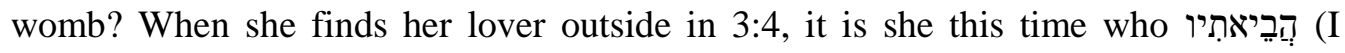

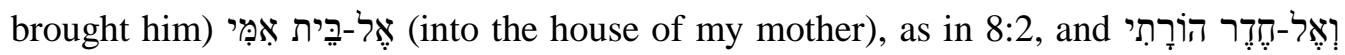
(into the room of the one who gave birth to me). He then tries to do it himself by putting his hand (with the possibility of it being a euphemism for his penis perhaps due to the similar elongated shape of both body parts or due to them both being on the same level when the hands hang down) מִן-הָר (through the (key)hole) in 5:4. The etymological connotation of piercing (Brown, Driver and Briggs 1951:359) suggests his penetration through the orifice that gives access to her "house" representing her body, and more particularly her womb (cf also Freud 1986:225). The association between these two as symbols for the "Weiblich-Mütterliche" will also occur again in 8:2 (Krinetzki 1981:212). Reminiscent of psychodynamic associations between a house and the body as containers, and therefore representations of the self (Jung 
1984:116; Freud 1929:128f.; 1986:85, 225), houses are mentioned in the explicit and literal sense but suggesting their figurative function as well: רִִּּ (our houses) and its inflexions are used first as a representation of the lovers' rendezvous in 1:17 and implied in 2:9. It is then used in combination with היזיזין 2:4, and implied in 3:1f and $5: 2 \mathrm{f}$ when there is reference to the home of the beloved. It further refers to her

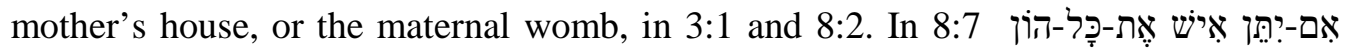
(if a man would give all the wealth of his house), "he would be ridiculed" might also mean that love cannot be other than reduced to the body as well. In thesis: feminine archetypes such as house, water, spring, fountain, river, and death.

From all of these various metaphors and similes, despite the multiplicity of nuances which they sometimes grant the same body-part, it is clear that no one can get a hold on any body/anybody, that the real bodies elude all the descriptions and that the body-images are therefore also always illusions. The body is always described in terms of what it really is not. Secondly, it is the environment which shapes both the body and its images.

\section{CONCLUSION}

The focus on the mouth of the male and the breasts of the female lover suggests that there is a regression (which is completely normal and healthy) to the oral phase during the time that the mother was still an extension of the infant's body or the only other important person. That is perhaps why no father-figure disrupts this union, unless Solomon is regarded as rival.

Not only is there is clear concentration on the female's mouth with its lips, teeth, tongue, and even palate or gums, but more specifically, on her breasts, to which the eyes are unconsciously linked. It is during this oral phase that the infant's vision is free to focus on the maternal face, more specifically her eyes.

Despite numerous projections by recipients, there is no implicit genital intercourse. In fact, almost right at the end, in 8:10, the female lover claims to be (a wall), as an euphemism for her hymen: she is still a virgin, as the male lover already 
found in 4:12 where she is called a sealed fountain and in 5:2 and 6:9 where she is תַתָמָת (my undefiled or perfect one).

The question can be raised if there is a reduction to what is seen as the essence of the female lover, her breasts, so that she is still only loved as a part-object. In the romantic atmosphere the bodies of the lovers are, however, deified which is exactly what the infant does to that of his mother.

\section{BIBLIOGRAPHY}

Almansi, R J 1960. The face-breast equation, Journal of the American Psychoanalytic Association 8:43-70.

Asher-Greve, J M 1998. The essential body: Mesopotamian conceptions of the gendered body, in Wyke 1998:8-37.

Baumann, G 2003. Das göttlichen Geschlecht. JHWHs Körper und die Gender-Frage, in Hedwig-Jahnow-Forschungsprojekt 2003:220-250.

Brown, F, Driver, S R, and Briggs, C A 1907. A Hebrew and English Lexicon of the Hebrew Bible with an appendix containing the Biblical Aramaic. Oxford: Clarendon.

Cauvin, J 2000. The birth of the gods and the origins of agriculture. Cambridge: University Press.

De la Porte, A E, Joubert, N L and Oberholzer, A E (eds) 2017 forthcoming. Wholeness in healthcare: Proceeds of the 2nd Biennial Conference on Spirituality and Healthcare. Newcastle: Cambridge Scholar Press.

Douglas, M 1970. Natural symbols. London: Barrie and Rockliff the Cresset.

Fairbairn, W R D 2006. Psychoanalytic studies of the personality. London: Routledge.

Feher, M 1989. Introduction, in Feher, Nadaf and Tazi 1989:10-17.

Feher, M, Naddaff, R, and Tazi, N (eds) 1989. Fragments for a history of the human body. Part one. New York: Zone Books.

Fischer, M 1992. The future of the body: explorations into the further evolution of human nature. Los Angeles: Jeremy P. Tarcher.

Fisher, S 1989. Sexual images of the self: the psychology of erotic sensations and illusions. Hillsdale: Lawrence Erlbaum Associates.

Fisher, S and Greenberg, R P1979. Body opening symptoms and right-left sets, Journal of Nervous and Mental Illness 167:422-427.

Freud, S [1917] 1929. Introductory lectures on psycho-analysis. London: George Allen \& Unwin.

[1905] 1974. Drei Abhandlungen zur Sexualtheorie und verwandte Schriften.

Frankfurt am Main: Fischer.

[1900] 1986. The interpretation of dreams. London: George Allen \& Unwin.

Gadamer, G 1960. Wahrheit und Methode. Grundzüge einer philosophischen Hermeneutik. Tübingen: Mohr.

Gerleman, G 1965. Ruth. Das Hohelied. Neukirchen-Vluyn: Neukirchener Verlag/Moors.

Hanks, T 2014. Sexo, sufrimiento, sabiduría y mujeres: Cantar de los cantares, Job, Lamentaciones, Proverbios, Qohelet (Eclesiastés), Ruth, Esther. La Biblia Hebrea 
subversiva: liberación para todas / os las / los oprimidas /os. Una guía para la lectura de la Biblia Hebrea. Buenos Aires: Epifania.

Hedwig-Jahnow-Forschungsprojekt 2003. Körperkonzepte im Ersten Testament. Aspekte einer Feministischen Anthropologie. Stuttgart: W. Kohlhammer.

Jewish Publication Society of America 1917. The Holy Scriptures according to the Masoretic Text: a new translation with the aid of previous versions and with constant consultation of Jewish Authorities.

Jung, C G 1984. Dream analysis: notes of the seminar given in 1928-1930. Princeton: University Press.

Keel, O 1986. Das Hohelied. Zürich: Theologische Verlag.

Klein, M R 1975. Envy and gratitude and other works 1946-1963. Hogarth Press and the Institute of Psycho-Analysis.

Krinetzki, G 1981. Kommentar zum Hohenlied: Bildsprache und theologische Botschaft. Frankfurt: Lang.

Leeming, D A 2004. Jealous gods and chosen people: the mythology of the Middle East. Oxford: University Press.

Loader, J A 1998-2001. Exegetical erotica to Canticles 7: 2-6, Journal for Semitics 10/12:98-111.

Munro, J M 1995. Spikenard and saffron: a study in the poetic language of the Song of Songs. Sheffield: Academic Press.

Pope, M H 1977. Song of Songs: a new translation with introduction and commentary. New York: Doubleday.

Ricœur, P 1965. De l'interprétation: Essai sur Freud. Paris: Maison d'éditions du Seuil.

Van der Zwan, P 2017 (forthcoming). The ideal body and the celebration of health in the book of Song of Songs in the Hebrew Bible, in de la Porte, Joubert and Oberholzer 2017.

Viviers, H 1998. A socio-rhetorical evaluation of some ideological readings of the Song of Songs, Ekklesiastikos Pharos 80/1:1-12. forthcoming. Another look at "wild nature" in the Song of Songs.

Wilber, K E 2001. The eye of spirit. Boston: Shambhala.

Williams, M A 1989. Divine image - prison of flesh: perceptions of the body in ancient Gnosticism, in Feher, Naddaff , and Tazi 1981:128-147.

Wyke, M (ed.). 1998b. Gender and the body in the ancient Mediterranean. Oxford: Blackwell. 